\title{
Tubeimoside I sensitizes cisplatin in cisplatin-resistant human ovarian cancer cells (A2780/DDP) through down-regulation of ERK and up-regulation of p38 signaling pathways
}

\author{
HAI-ZHONG LIU ${ }^{1 *}$, CHAO YU $^{2 *}$, ZHU YANG ${ }^{1}$, JUN-LIN HE ${ }^{2}$, WEN-JUAN CHEN ${ }^{1}$, JUAN YIN ${ }^{1}$, \\ WEN-MING $\mathrm{LI}^{2}$, HONG-TAO LIU ${ }^{2}$ and YING-XIONG WANG ${ }^{2}$ \\ ${ }^{1}$ Department of Obstetrics and Gynecology, Second Affiliated Hospital of Chongqing Medical University, Chongqing 400010; \\ ${ }^{2}$ Institute of Life Sciences, Chongqing Medical University, Chongqing 400016, P.R. China
}

Received February 28, 2011; Accepted June 15, 2011

DOI: $10.3892 / \mathrm{mmr} .2011 .513$

\begin{abstract}
Cisplatin (CDDP) is a major chemotherapeutic drug used in the treatment of human ovarian cancer. Tubeimoside I (TBMS1) has also shown potent antitumor and antitumorpromoting effects, and may offer a promising new approach in the effective treatment of CDDP-resistant human ovarian cancers. This study aimed to investigate the effect of TBMS1 in sensitizing CDDP in CDDP-resistant human ovarian cancer cells (A2780/DDP). A variety of methods were employed to measure cell apoptosis, p38, ERK1/2 and glutathione S-transferase (GST)- $\pi$ expressions. It was found that TBMS1 combined with CDDP promoted cell apoptosis, decreased proliferation activity and increased cytosolic $\mathrm{Ca}^{2+}$ levels. Bcl-2 protein expression was down-regulated but Bax was up-regulated. Moreover, GST- $\pi$ mRNA and protein expression were decreased. TBMS1 reduced the resistance of the cells to CDDP-induced cytotoxicity. Both the p38 inhibitor (SB203580) and the ERK1/2 inhibitor (PD98059) effectively blocked this effect. These results suggest that TBMS1 can effectively sensitize CDDP in CDDP-resistant human ovarian cancer cells through the down-regulation of the ERK1/2 and the up-regulation of the p38 signaling pathways.
\end{abstract}

\section{Introduction}

Cisplatin [cis-diamminedichloroplatinum (II); CDDP] is a major chemotherapeutic drug used to treat human ovarian cancer. It is capable of exerting its cytotoxcity on ovarian cancer via the formation of intra- and interstrand CDDP-DNA adducts, which may ultimately result in cell cycle arrest at

Correspondence to: Dr Zhu Yang, Department of Obstetrics and Gynecology, Second Affiliated Hospital of Chongqing Medical University, Chongqing 400010, P.R. China

E-mail: cqyangz@vip.163.com

*Contributed equally

Key words: tubeimoside I, cisplatin, ovarian cancer, signaling pathway
$\mathrm{G} 1, \mathrm{~S}$, or G2-M, and the induction of genetically programmed cell death (1). However, its efficacy is limited due to the development of drug resistance in cancer cells. The majority of patients with ovarian cancer are not effectively treated with standard CDDP regimens primarily due to the obstacle posed by the development of drug resistance (2). Resistance to CDDP occurs in roughly one-third of women during primary treatment and in all patients treated for recurrent disease (3).

The combination of innocuous dietary components with anticancer drugs is an emerging new strategy in cancer chemotherapy to increase antitumor responses (4). Tubeimoside I (TBMS1), a triterpenoid saponin isolated from the tubers of Bolbostemma paniculatum, has shown potent antitumor and antitumor-promoting effects (5). However, little is known about its activity in chemoresistant cells. TBMS1 may offer a promising new approach in the effective treatment of CDDPresistant human ovarian cancers.

Bcl-2 protein family members are the best characterized proteins to have direct involvement in the regulation of apoptosis (6). Bcl-2 and its closest homologs, $\mathrm{Bcl}-\mathrm{xL}$ and $\mathrm{Bcl}-\mathrm{w}$, potently inhibit apoptosis in response to many cytotoxic insults (7). Bax and Bak are well known pro-apoptotic members of the Bcl-2 protein family (8). Regulation of apoptosis is highly dependent on the ratio of anti-apoptotic to pro-apoptotic proteins (9).

The mechanism by which MAPK signaling regulates apoptosis has long been studied, and the involvement of the Bcl-2 family has been noted $(10,11)$. Moreover, the MAPK pathway and the activation of cell signaling pathways is a common feature of cancer cells and can influence the cellular response following drug treatment $(12,13)$. It has originally been shown that ERKs are essential for cell survival, whereas JNKs and p38-MAPKs have been deemed stress-responsive and thus involved in apoptosis (14). The MAPK pathway has been implicated in cancer cell apoptosis and is induced by several chemotherapeutic drugs, including CDDP (15).

GST- $\pi$ is a member of the glutathione S-transferase (GST) family. GSTs are a supergene family of phase II metabolic enzymes (16). GST enzymes are coded by at least eight distinct loci: $\alpha$ (GSTA), $\mu$ (GSTM), $\theta$ (GSTT), $\pi$ (GSTP), $\sigma$ (GSTS), $\kappa$ (GSTK), o (GSTO) and $\tau$ (GSTZ), each of which contains one or more homodimeric or heterodimeric isoforms $(17,18)$. It has 
been postulated that the GST enzymes and the genes encoding these may be involved in the susceptibility to cancer (19). High GST- $\pi$ activity may result in a more rapid drug metabolism that diminishes the cytotoxic effects of chemotherapy on tumor cells (20).

In the present study, the potential of the triterpenoid saponin, TBMS1, to sensitize the CDDP-resistant human ovarian cancer A2780/DDP cells to CDDP-induced cytotoxicity was investigated, and the underlying mechanism of its action was identified.

\section{Materials and methods}

Chemicals and reagents. Rabbit anti-p38, anti-phospho-p38 (p-p38), anti-ERK1/2, anti-p-ERK1/2 and GST- $\pi$ antibodies were obtained from Santa Cruz Biotechnology (Santa Cruz, CA, USA). CFSE was obtained from Sigma (St. Louis, MO, USA). The p38 MAPK inhibitor (SB203580) and ERK1/2 inhibitor (PD98059) were purchased from Invitrogen Corp. (Carlsbad, CA, USA). RPMI-1640 medium and fetal bovine serum (FBS) were obtained from Gibco (Grand Island, NY, USA). TRIzol reagent was obtained from Takara (Dalian, China).

Cell culture and treatment. The CDDP-resistant human ovarian cancer A2780/DDP cells (obtained from the Laboratory of Obstetrics and Gynecology, Tongji Medical College of Huazhong University of Science and Technology) were grown in RPMI-1640 supplemented with $10 \%$ FBS at $37^{\circ} \mathrm{C}$ in a humidified $5 \% \mathrm{CO}_{2}$ atmosphere. The p38 inhibitor (SB203580) and the ERK inhibitor (PD98059) were purchased from Invitrogen Corp. For all experiments, after growing to sub-confluence, cells were treated with various treatment concentrations: Vehicle, TBMS1 $(6 \mu \mathrm{mol} / 1)$, CDDP $(8 \mu \mathrm{mol} / 1)$, TBMS1 $(6 \mu \mathrm{mol} / \mathrm{l})$ and CDDP $(8 \mu \mathrm{mol} / \mathrm{l})$.

Reverse transcription-polymerase chain reaction (RT-PCR). Total RNA was extracted using cold TRIzol reagent (Takara) according to the manufacturer's instructions. The OD260 and OD260/280 values were measured with a spectrophotometer to determine the RNA concentrations. Reverse transcription was performed at $42^{\circ} \mathrm{C}$ for $1 \mathrm{~h}$, followed by incubation at $95^{\circ} \mathrm{C}$ for $5 \mathrm{~min}$. The reaction mixture (10 $\mu \mathrm{l}$ total volume) consisted of $1 \mu \mathrm{g}$ total RNA, 25 pmol oligo-dT primer, $10 \mathrm{nmol}$ dNTP mixture, 20 units RNase inhibitor and 2.5 units AMV reverse transcriptase (Bioer, Hangzhou, China). PCR amplification was performed in $20 \mu \mathrm{l}$ PCR reaction mixture containing $1 \mu \mathrm{l}$ cDNA reaction mixture, $10 \mathrm{nmol}$ dNTP mixture, $10 \mathrm{pmol}$ up- and downstream primers and 2 units BioReady ${ }^{\mathrm{TM}}$ rTaq polymerase (Bioer).

The following primers for RT-PCR were used: GST- $\pi$ (255 bp): Sense, 5'-ACC TGC CTG TGA CAT CAT-3'; antisense, 5'-TCT CCC TTT GTG CGT TCT-3' and GAPDH (230 bp): Sense, 5'-CTC TCT GCT CCT CCT GTT CGA CAG-3'; antisense, 5'-GTG GAA TCA TAT TGG AAC ATG T-3'. For PCR amplification, initial denaturation was performed for $4 \mathrm{~min}$ at $94^{\circ} \mathrm{C}, 30$ cycles x $30 \mathrm{sec}$ at $94^{\circ} \mathrm{C}, 30 \mathrm{sec}$ at $54^{\circ} \mathrm{C}$ and $30 \mathrm{sec}$ at $72^{\circ} \mathrm{C}$ for GAPDH. For GST- $\pi, 30$ cycles x $30 \mathrm{sec}$ at $94^{\circ} \mathrm{C}$ were performed, then $30 \mathrm{sec}$ at $56^{\circ} \mathrm{C}$ and $30 \mathrm{sec}$ at $72^{\circ} \mathrm{C}$. Gels were visualized for PCR product analysis, and $6 \mu \mathrm{l}$ PCR product from each sample was electrophoresed on a $1.2 \%$ agarose gel containing $0.1 \mu \mathrm{g} / \mathrm{ml}$ dye (GoldView ${ }^{\mathrm{TM}}$, SBS Genetech, Beijing, China). Gels were visualized and photographed by a GelDoc ${ }^{\mathrm{TM}}$ image analyzer (Bio-Rad, Hercules, CA, USA). The band intensity was analyzed with the Image J system (NIH, USA) and presented as a percentage of GAPDH expression.

Colony formation assay for long-term cell survival. The A2780/DDP cells were trypsinized and seeded in fresh culture medium at a density of 200 cells in 6-well plates. After cells were grown for 10 days, they were treated with the vehicle, CDDP $(6 \mu \mathrm{mol} / 1)$, TBMS1 $(8 \mu \mathrm{mol} / 1)$, CDDP $(6 \mu \mathrm{mol} / 1)$ and TBMS1 $(8 \mu \mathrm{mol} / \mathrm{l})$ drug combinations for $24 \mathrm{~h}$, respectively. Then, the cell colonies were fixed with $70 \%$ ethanol and stained with crystal violet $(0.5 \%$ in ethanol). The plates were rinsed with water, air-dried, photographed and evaluated for colony estimation.

Flow cytometric evaluation of cell proliferation and intracellular $\mathrm{Ca}^{2+}$ level. A2780/DDP cells plated in $25 \mathrm{~cm}^{2}$ culture flasks were assessed by flow cytometry for cell proliferation and intracellular $\mathrm{Ca}^{2+}$ levels following treatment with various drug concentrations.

The non-fluorescent dye, CFSE, can be cleaved by intracellular esterases to form fluorescent conjugates with amines and the dye-protein adducts are equally inherited by daughter cells following cell division. Therefore, the proliferation activity of cells can be accurately evaluated by the average fluorescence intensity, which is negatively correlated with the divided cell number. For flow cytometric evaluation of cell proliferation, A2780/DDP cells were labeled with CFSE $(20 \mu \mathrm{mol} / \mathrm{l})$ in RPMI-1640 (10\% FBS) for $5 \mathrm{~h}$ at $37^{\circ} \mathrm{C}$. The culture medium was then washed away and cells were treated with various drug concentrations. Following the treatment, cells were washed, harvested and re-suspended with PBS. The fluorescence in the cells was quantitatively analyzed at an emission wavelength of $530 \mathrm{~nm}$ and an excitation wavelength of $480 \mathrm{~nm}$ using a Vantage SE flow cytometer with a fluorescence-activated cell sorting (FACS) system (Becton Dickinson, San Jose, CA, USA).

The non-fluorescent dye, fluo-3 AM, was used for intracellular $\mathrm{Ca}^{2+}$ detection. Upon diffusion into cells, fluo-3 AM can be cleaved into fluo-3 by endogenous esterases and trapped inside the cells. After binding to $\mathrm{Ca}^{2+}$, fluo-3 elicits fluorescent light, which is proportional to the intracellular $\mathrm{Ca}^{2+}$ level. In brief, following drug treatment, cells were washed and incubated with RPMI-1640 (10\% FBS) containing $0.5 \mu \mathrm{mol} / 1$ of fluo-3 $\mathrm{AM}$ for $1 \mathrm{~h}$ at $37^{\circ} \mathrm{C}$. The cells were then washed, harvested, re-suspended with PBS and analyzed by flow cytometer.

Western blot analysis. According to the manufacturer's instructions (Beyotime Institute of Biotechnology, Jiangsu, China), following treatment with various drug concentrations (the vehicle, $6 \mu \mathrm{mol} / 1 \mathrm{CDDP}, 8 \mu \mathrm{mol} / 1 \mathrm{TBMS} 1,6 \mu \mathrm{mol} / 1 \mathrm{CDDP}+$ $8 \mu \mathrm{mol} / \mathrm{l} \mathrm{YBMS} 1$ ), the cells were washed twice in ice-cold PBS and lysed with RIPA lysis buffer (50 mM Tris at pH 7.4, $150 \mathrm{mM}$ $\mathrm{NaCl}, 1 \%$ Triton $\mathrm{X}-100,1 \%$ sodium deoxycholate, $0.1 \%$ SDS and $0.05 \mathrm{mM}$ EDTA). After being maintained in ice for $25 \mathrm{~min}$, the samples were centrifuged at $12,000 \mathrm{x}$ g for $15 \mathrm{~min}$ at $4^{\circ} \mathrm{C}$ and the supernatant was collected as the total cell lysate. All samples were stored at $-80^{\circ} \mathrm{C}$ for further experiments. Protein samples $(50 \mu \mathrm{g})$ were boiled in $5 \mathrm{X}$ loading buffer $(125 \mathrm{mM}$ 
A

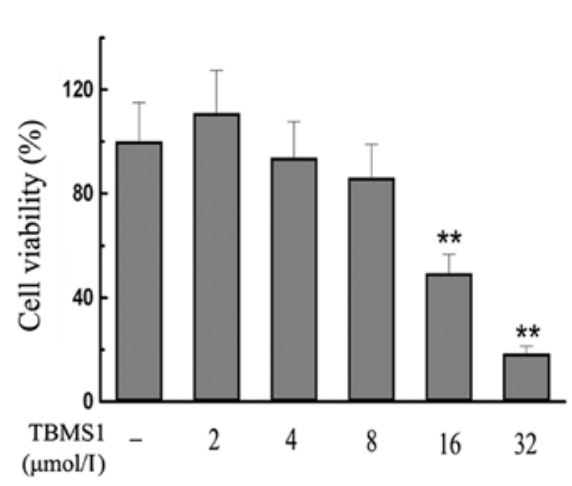

B

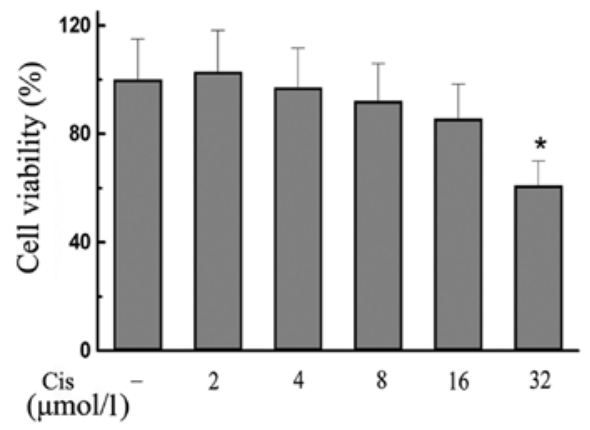

C

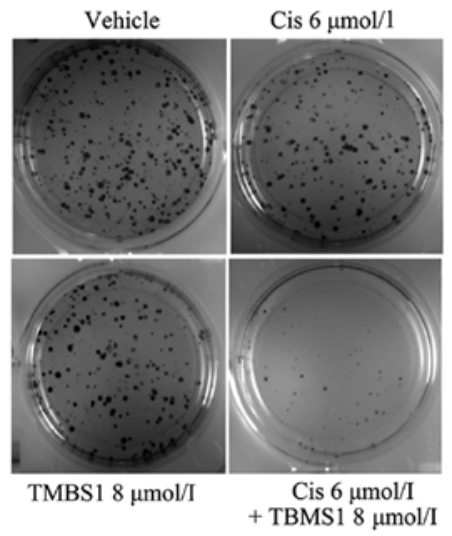

D

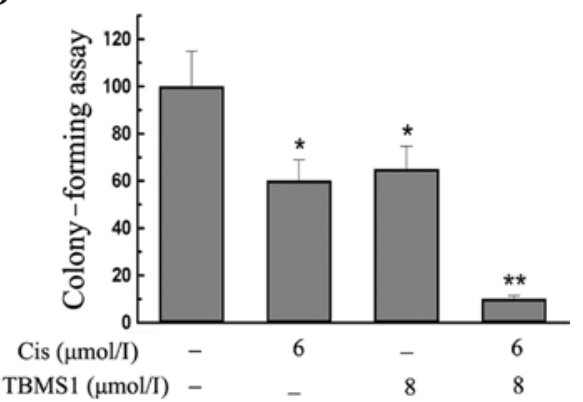

Figure 1. Effect of TBMS1 and CDDP on the cell viability of A2780/DDP cells. Cells were pretreated with (A) TBMS1 and (B) CDDP (2-32 $\mu$ mol/l) for 24 h. Following the treatment, cell viability was determined by MTT analysis ( $\mathrm{n}=3)$. (C) Cells were pretreated with the vehicle, TBMS1 (6 $\mu$ mol/1), CDDP ( $4 \mu \mathrm{mol} / \mathrm{l})$, TBMS1 $(6 \mu \mathrm{mol} / \mathrm{l})$ and CDDP $(8 \mu \mathrm{mol} / \mathrm{l})$ for $24 \mathrm{~h}$ to test colony forming assay. (D) Detection of colony forming numbers. Data are expressed as the means \pm SD. ${ }^{*} \mathrm{P}<0.05$ and ${ }^{* *} \mathrm{P}<0.01$, compared to the vehicle-treated group. Cis, cisplatin (CDDP).

Tris- $\mathrm{HCl}$ at $\mathrm{pH} 6.8,10 \%$ SDS, $8 \%$ dithiothreitol, $50 \%$ glycerol and $0.5 \%$ bromochlorophenol blue) for $10 \mathrm{~min}$. These samples were electrophoretically fractionated with a discontinuous system consisting of $10-15 \%$ polyacrylamide resolving gels and 5\% stacking gels, and then transferred to nitrocellulose membranes (Amersham, Buckinghamshire, UK) at $30 \mathrm{~V}$ and $250 \mathrm{~mA}$ (current constant) for 45-90 min.

The membranes were blocked with $5 \%$ skimmed milk in PBS with $0.1 \%$ Tween-20 (PBST) for $1 \mathrm{~h}$, and incubated with primary antibodies against $\mathrm{Bcl}-2$, Bax, GST- $\pi$ and $\beta$-actin protein and anti-p38, anti-ERK1/2, anti-phospho-p38 and anti-p-ERK $1 / 2$ antibodies overnight at $4^{\circ} \mathrm{C}$. They were then incubated with an appropriate HRP-conjugated secondary antibody at $37^{\circ} \mathrm{C}$ for $1 \mathrm{~h}$. The membranes were washed and examined by chemiluminescence detection and densitometric analysis on a ChemiDoc ${ }^{\mathrm{TM}}$ image analyzer (Bio-Rad).

Statistical analysis. The data were represented as the means \pm SD. One-way analysis of variance (ANOVA) and the Student's t-test were carried out to determine statistical significance. A value of $\mathrm{P}<0.05$ was considered statistically significant. All experiments were repeated in triplicate.

\section{Results}

TBMS1 sensitizes A2780/DDP cells to low-dose CDDPinduced death. First, the antiproliferative effects of TBMS1 and CDDP were examined in CDDP-resistant A2780/DDP cells (Fig. 1A and B). Low-dose CDDP (6 $\mu \mathrm{mol} / 1)$ was then selected, which kills approximately $5 \pm 13.6 \%$ of resistant cells, and this was combined with low-dose TBMS1 $(8 \mu \mathrm{mol} / \mathrm{l})$, which kills approximately $13.9 \pm 12.9 \%$, to further test whether this combination is capable of enhancing the growth inhibition of CDDP-resistant cells. The results of the colony-forming assay (Fig. 1C) confirmed that the combination of TBMS1 with a low dose of CDDP elicits a significantly higher cytotoxic response in CDDP-resistant human ovarian cancer cells.

TBMS1 inhibits CDDP-induced proliferation in A2780/DDP cells. The effect of TBMS1 on cell proliferation in CDDP-induced A2780/DDP cells was investigated using the intracellular dye, CFSE. The results in Fig. 2 show that the fluorescence intensity in A2780/DDP cells was minimal with low-dose CDDP (4.22 \pm 9$) \%$ or TBMS1 $(10.12 \pm 1.3) \%,(\mathrm{P}<0.05$, vs. the vehicle-treated group) but a significant increase was observed following exposure to a combination of TBMS1 with low-dose CDDP $(22.79 \pm 0.2) \%$, ( $\mathrm{P}<0.01$, vs. the vehicle-treated group).

TBMS1 strengthens CDDP-induced $\mathrm{Ca}^{2+}$ influx in A2780/ $D D P$ cells. Since cytosolic $\mathrm{Ca}^{2+}$ plays a significant role in the regulation of cell growth and death, the effect of TBMS1 on strengthening the CDDP-induced $\mathrm{Ca}^{2+}$ influx in A2780/DDP cells was determined. Cells were pretreated with the vehicle, TBMS1 $(6 \mu \mathrm{mol} /)$ CDDP $(8 \mu \mathrm{mol} / 1)$ or TBMS1 $(6 \mu \mathrm{mol} / 1)$ plus CDDP $(8 \mu \mathrm{mol} / \mathrm{l})$ for $24 \mathrm{~h}$. As shown in Fig. 3, TBMS1 significantly increased the CDDP-induced $\mathrm{Ca}^{2+}$ influx in A2780/DDP cells $(51.99 \pm 3.2) \%,(\mathrm{P}<0.01$, vs. the vehicle-treated group).

TBMS1 enhances CDDP-induced apoptosis via a Bcl-2 and Bax-dependent mechanism. To explore the molecular mechanisms of TBMS1 on CDDP-induced apoptosis, the protein expression of Bcl-2 and Bax was examined in A2780/DDP cells 

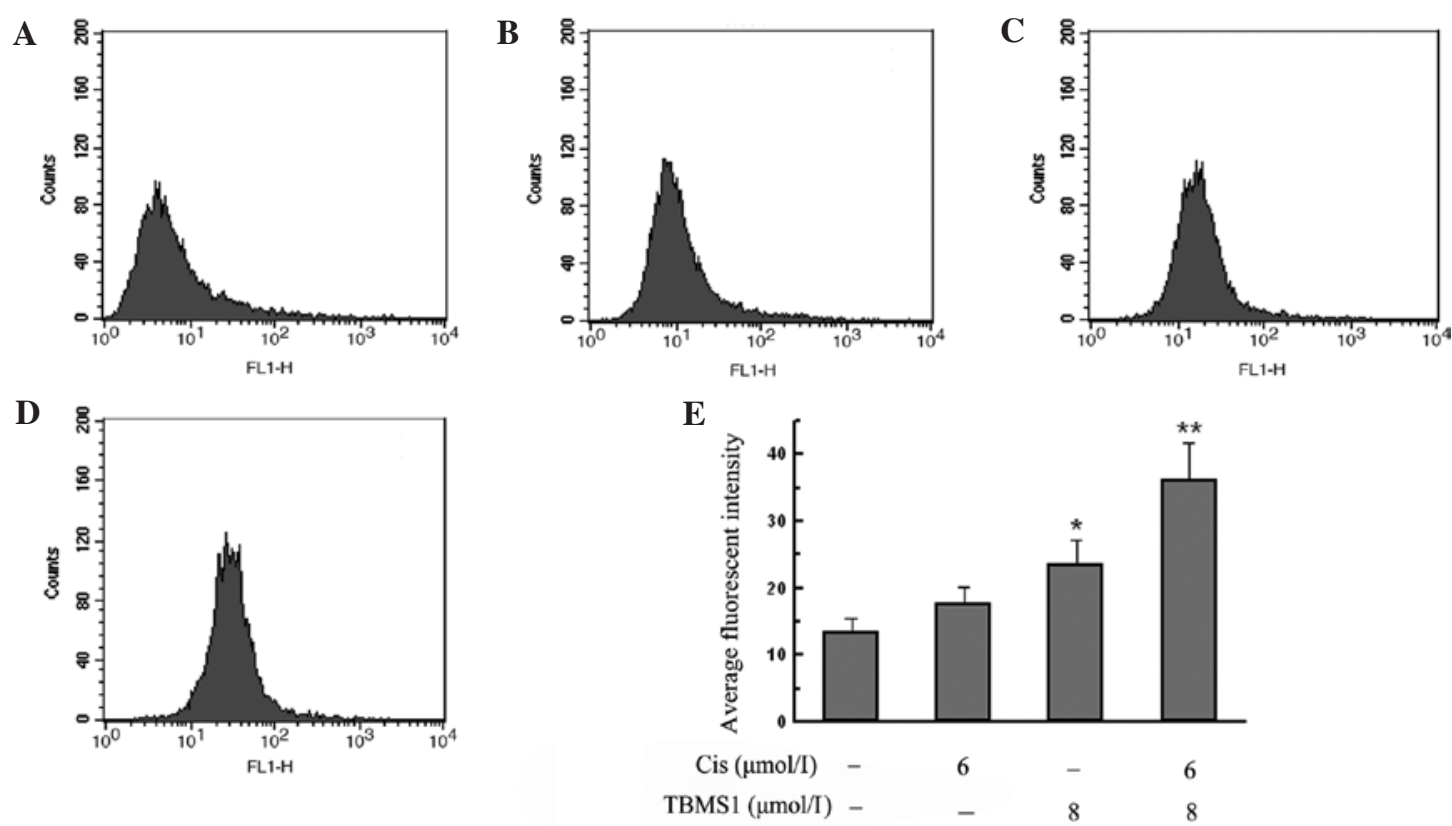

Figure 2. Effect of TBMS1 on CDDP-inhibited cell proliferation of A2780DDP cells. Cells were pretreated with (A) the vehicle, (B) TBMS1 (6 $\mu$ mol/1), (C) CDDP $(8 \mu \mathrm{mol} / 1)$, (D) TBMS1 $(6 \mu \mathrm{mol} / 1)$ and CDDP $(8 \mu \mathrm{mol} / 1)$ for $24 \mathrm{~h}$. Following the treatment, cell proliferation was evaluated by flow cytometry. (E) Fluorescence intensities of A2780/DDP cells treated with vehicle. Data are expressed as the means $\pm \mathrm{SD}(\mathrm{n}=3)$. "P<0.05, ${ }^{* *} \mathrm{P}<0.01$, compared to the vehicletreated group. Cis, cisplatin (CDDP).
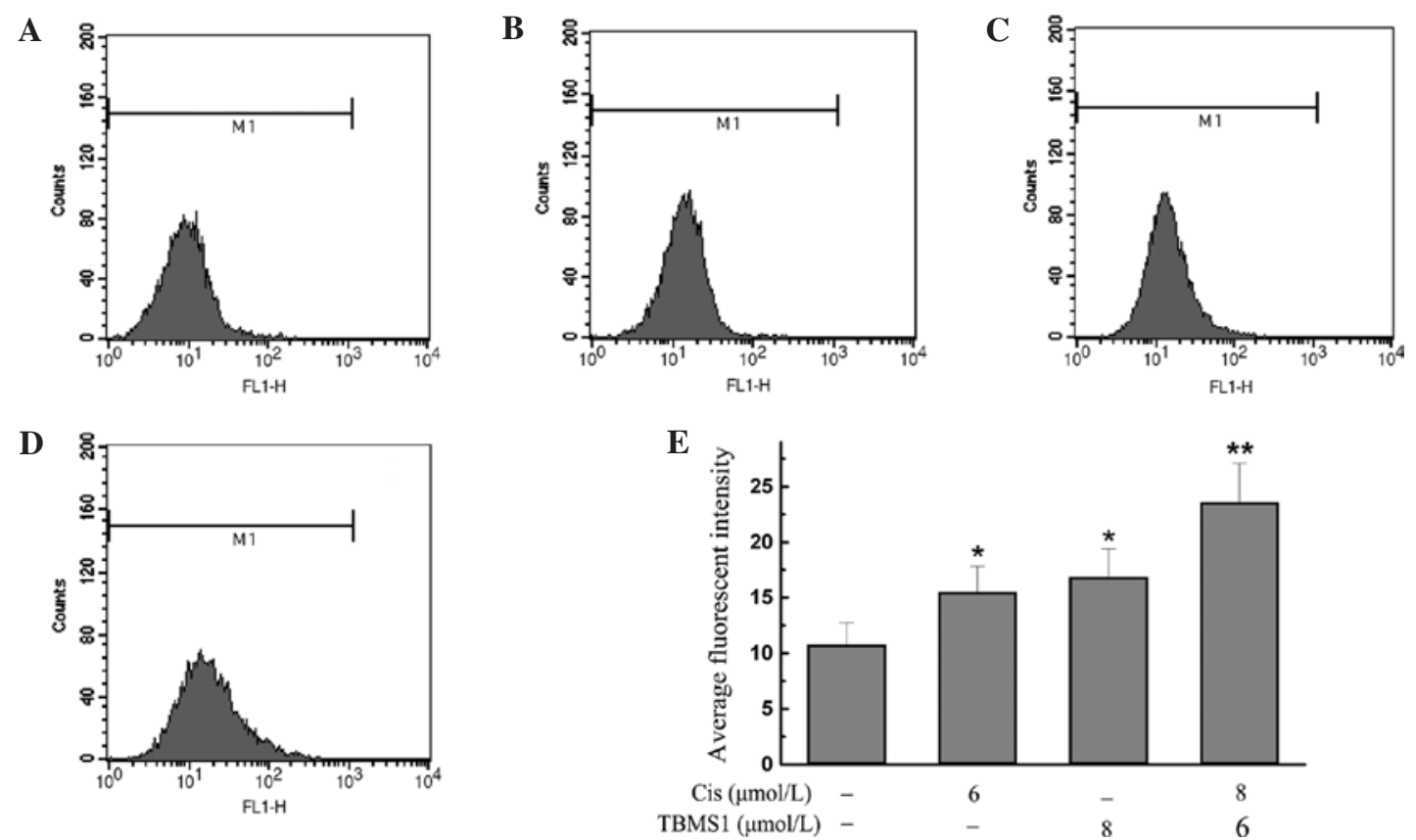

Figure 3. Effect of TBMS1 on CDDP-induced $\mathrm{Ca}^{2+}$ influx in A2780/DDP cells. Cells were pretreated with (A) the vehicle, (B) TBMS1 (6 $\left.\mu \mathrm{mol} / 1\right)$, (C) CDDP $(8 \mu \mathrm{mol} / \mathrm{l}),(\mathrm{D}) \mathrm{TBMS1}(6 \mu \mathrm{mol} / \mathrm{l})$ and CDDP $(8 \mu \mathrm{mol} / \mathrm{l})$ for $24 \mathrm{~h}$. (A-D) Cytosolic $\mathrm{Ca}^{2+}$ level in A2780/DDP cells was determined by flow cytometry as described in Materials and methods. (E) Fluorescence intensities of A2780/DDP cells treated with vehicle. Data are expressed as the means $\pm S D(n=3)$. ${ }^{*} P<0.05,{ }^{* *} \mathrm{P}<0.01$, compared to the vehicle-treated group. Cis, cisplatin (CDDP).

using Western blot analysis, as shown in Fig. 4. As expected, the $\mathrm{Bcl}-2$ protein level was decreased to $(22.4 \pm 3.9) \%$, $(\mathrm{P}<0.01$ vs. the vehicle-treated group) in the single CDDP-treated group following exposure to TBMS1 combination. Contrary to this, the combination of TBMS1 with a low dose of CDDP increased the Bax protein level $(40.2 \pm 5.2) \%$, $(\mathrm{P}<0.05$, vs. the vehicletreated group).
TBMS1-CDDP combination induces apoptosis in A2780/DDP cells by regulating MAPK signaling. To understand whether TBMS1 affects CDDP-induced MAPK activation, the effects of various treatment concentrations on CDDP-induced $\mathrm{p} 38$ and ERK1/2 activation in A2780/DDP cells, were examined. The phosphorylation of $\mathrm{p} 38$ was significantly increased and the phosphorylation of ERK1/2 was significantly decreased 


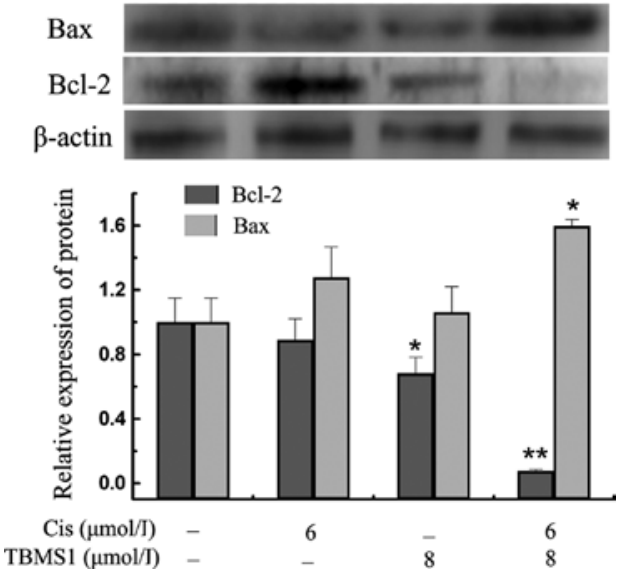

Figure 4. Effect of TBMS1 on the protein level of Bcl-2 and Bax in CDDPinduced A2780/DDP cells. Cells were pretreated with the vehicle, CDDP ( $6 \mu \mathrm{mol} / \mathrm{l})$, TBMS1 $(8 \mu \mathrm{mol} / \mathrm{l}), \mathrm{CDDP}(6 \mu \mathrm{mol} / \mathrm{l})$ and TBMS1 $(8 \mu \mathrm{mol} / \mathrm{l})$ for $24 \mathrm{~h}$. Following the treatment, the protein level of Bcl-2 and Bax was measured by Western blot analysis as described in Materials and methods. Data are expressed as the means $\pm \mathrm{SD}(\mathrm{n}=3)$. ${ }^{*} \mathrm{P}<0.05,{ }^{* *} \mathrm{P}<0.01$, compared to the vehicletreated group. Cis, cisplatin (CDDP).

A
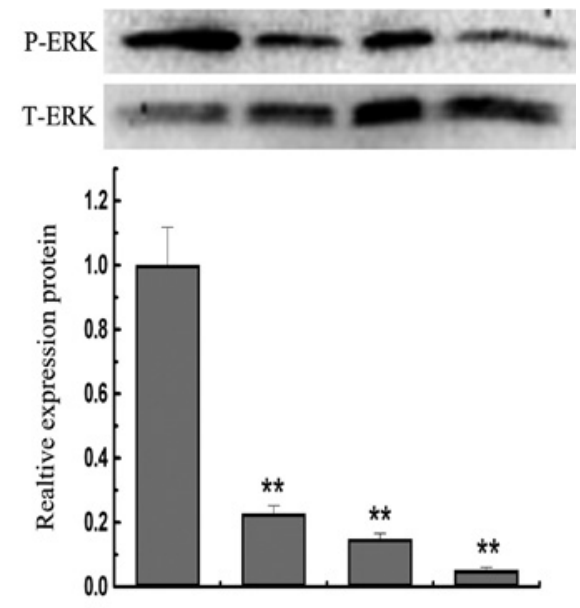

$\operatorname{Cis}(\mu \mathrm{mol} / \mathrm{I}) \quad-$ TBMS1 $(\mu \mathrm{mol} / \mathrm{I}) \quad-$

B
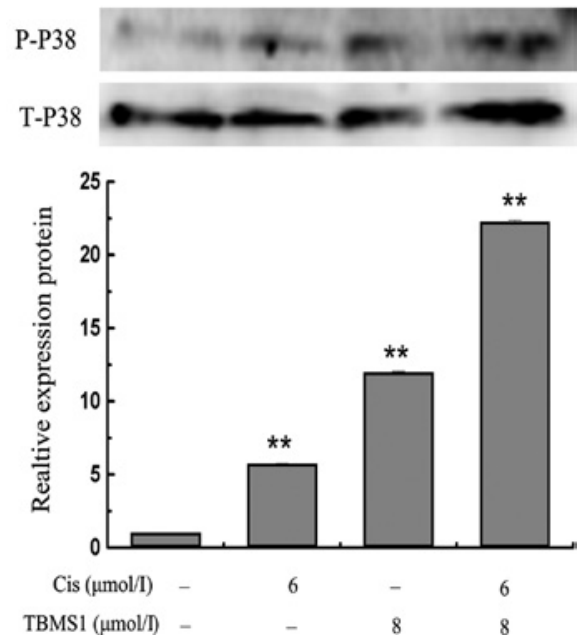

Figure 5. Effect of TBMS1 on the protein level of p-p38 and p-ERK1/2 in CDDP-induced A2780/DDP cells. Cells were pretreated with the vehicle, TBMS1 $(6 \mu \mathrm{mol} / 1), \mathrm{CDDP}(8 \mu \mathrm{mol} / \mathrm{l}), \mathrm{TBMS} 1(6 \mu \mathrm{mol} / \mathrm{l})$ and CDDP $(8 \mu \mathrm{mol} / \mathrm{l})$ for $24 \mathrm{~h}$. The intensity of the band of each (A) p-ERK and (B) p-p38 was corrected to that of total ERK1/2 and p38, respectively. Data are expressed as the means $\pm \mathrm{SD}(\mathrm{n}=3) .{ }^{*} \mathrm{P}<0.05,{ }^{* *} \mathrm{P}<0.01$, compared to the vehicle-treated group. Cis, cisplatin (CDDP).
A

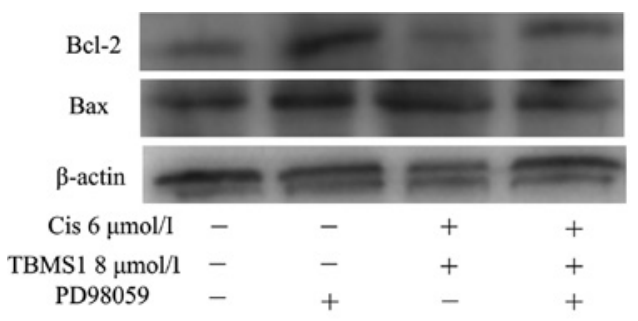

B

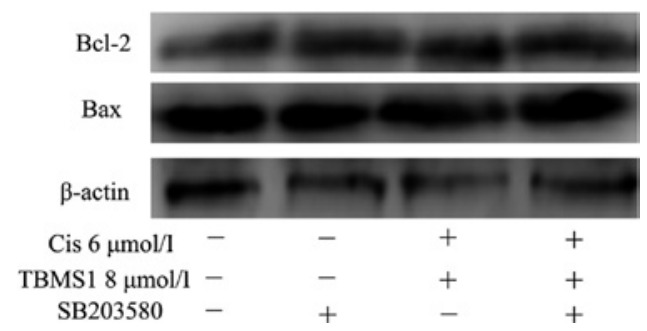

Figure 6. Effect of ERK and p38 inhibitors (PD98059 and SB203580) on Bcl-2 and Bax protein expression in A2780DDP cells. (A) Cells were pretreated with the vehicle, PD98059 (30 $\mu \mathrm{mol} / \mathrm{l})$, CDDP $(6 \mu \mathrm{mol} / \mathrm{l})$ and TBMS1 (8 $\mu \mathrm{mol} / \mathrm{l}), \mathrm{CDDP}(6 \mu \mathrm{mol} / \mathrm{l}), \mathrm{TBMS} 1(8 \mu \mathrm{mol} / \mathrm{l})$ and PD98059 $(30 \mu \mathrm{mol} / \mathrm{l})$ for $24 \mathrm{~h}$. (B) Cells were pretreated with the vehicle, SB203580 (25 $\mu \mathrm{mol} / \mathrm{l})$, CDDP $(6 \mu \mathrm{mol} / 1)$ and TBMS1 $(8 \mu \mathrm{mol} / 1), \mathrm{CDDP}(6 \mu \mathrm{mol} / 1)$, TBMS1 $(8 \mu \mathrm{mol} / 1)$ and SB203580 $(25 \mu \mathrm{mol} / \mathrm{l})$ for $24 \mathrm{~h}$. Following the treatment, protein levels of Bcl-2 and Bax were determined by Western blot analysis. The data are representative of three independent experiments (means \pm SEM). ${ }^{*} \mathrm{P}<0.05,{ }^{* *} \mathrm{P}<0.01$, compared to the controls. Cis, cisplatin (CDDP).

following treatment with the TBMS1-CDDP combination in A2780/DDP cells (Fig. 5). The results indicate that the phosphorylation of p38 and ERK1/2 is involved in the Bcl-2 and Bax expression induced by CDDP and that these pathways are regulated by TBMS1.

p38 and ERK1/2 inhibitors suppress CDDP-induced cellular apoptotic signaling pathways. To further confirm whether the modulation of the MAPK signaling pathway is involved in TBMS1-CDDP-induced apoptosis in resistant cells, the experiments were performed based on p38 inhibition (SB203580, $25 \mu \mathrm{mol} / \mathrm{l}$ ) and ERK1/2 inhibition (PD98059, $30 \mu \mathrm{mol} / \mathrm{l}$ ) in A2780/DDP cells. Cells were pre-incubated with the specific p38 and ERK1/2 inhibitors for $1 \mathrm{~h}$ then treated with TBMS1CDDP. Following $1 \mathrm{~h}$ pre-treatment with the $\mathrm{p} 38$ and ERK1/2 inhibitor, a total blockade of the TBMS1-CDDP-mediated change in apoptotic rate was noted (Fig. 6). This result indicate once again that $\mathrm{p} 38$ and ERK1/2 are crucial factors in CDDPinduced cellular apoptotic signaling pathways.

GST- $\pi m R N A$ and protein expressions in A2780/DDP cells are reduced by TBMS1-CDDP combination. Since GST- $\pi$ is associated with drug resistance, RT-PCR and Western blot analysis were used to examine the mRNA and protein expressions of GST- $\pi$. The treatment of A2780/DDP cells with a combination of TBMS1 and CDDP resulted in a greater decrease than in the control cells (Fig. 7). The results confirm that TBMS1 reduces the resistance of the cells to CDDP cytotoxicity.

\section{Discussion}

CDDP is one of the most widely used chemotherapeutic agents in the treatment of human ovarian cancer and other tumors (21). 
$\mathbf{A}$
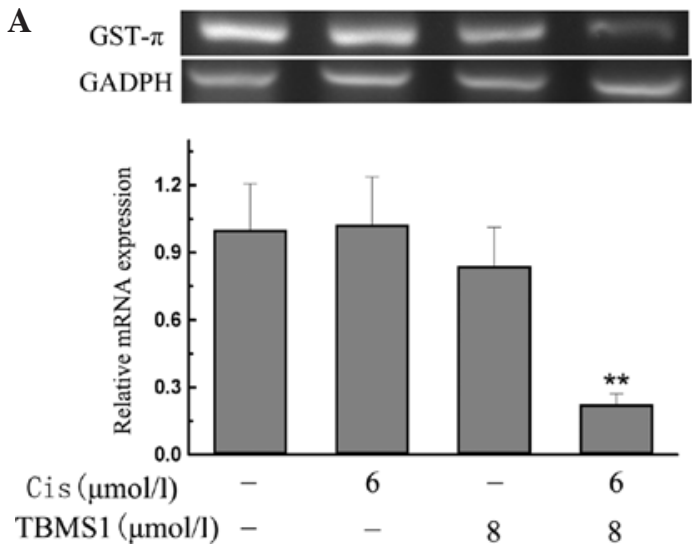

B
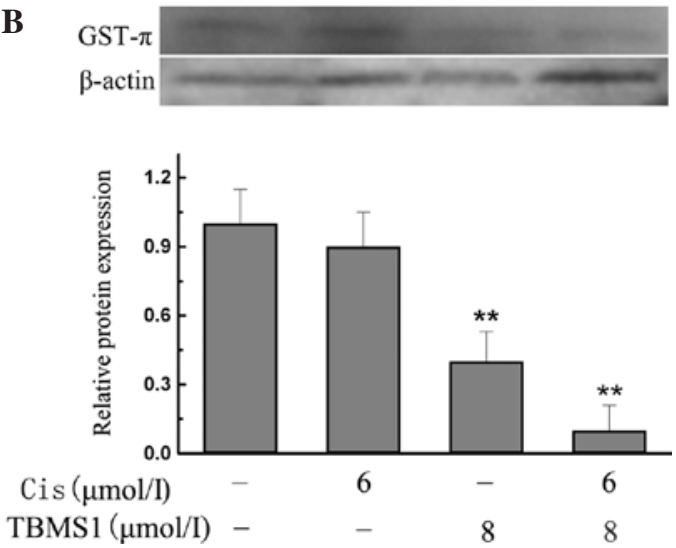

Figure 7. Effect of TBMS1 on cisplatin (CDDP)-induced in GST- $\pi$ of A2780/DDP cells. (A) Cells were pretreated with vehicle, TBMS1 (6 $\mu$ mol/1), CDDP $(8 \mu \mathrm{mol} / \mathrm{l})$, TBMS1 $(6 \mu \mathrm{mol} / \mathrm{l})$ and CDDP $(8 \mu \mathrm{mol} / \mathrm{l})$ for $24 \mathrm{~h}$. Following the treatment, GST- $\pi$ mRNA level was determined by RT-PCR analysis as described in Materials and methods. (B) Protein level of GST- $\pi$ was measured by Western blot analysis as described in Materials and methods. Data are expressed as the means $\pm \mathrm{SD}(\mathrm{n}=3) .{ }^{* * *} \mathrm{P}<0.01$, compared to the vehicle-treated group.

One of the major problems with CDDP treatment is the clinical development of resistance to this drug (22). Several mechanisms are responsible for CDDP resistance, including reduced platinum accumulation, enhanced platinum detoxification and metabolism and altered DNA damage repair (23).

CDDP plays a central role in platinum-based chemotherapy in the treatment of ovarian cancer, yet overcoming the acquired resistance continues to be a major clinical challenge. Over the years, there has been an increasing interest in combining chemotherapeutic agents with highly promising and relatively innocuous dietary flavonoids to induce the acquired resistance $(24,25)$. In this study, the effect of TBMS1 on sensitizing the CDDP-resistant ovarian cancer cells to CDDP-induced cytotoxicity was investigated.

TBMS1 has potent antitumor and antitumor-promoting effects (26-28). It is capable of inducing apoptosis in HeLa cells, as well as human promyelocytic leukemia (HL-60) and nasopharyngeal carcinoma cells (CNE-2Z) (29-31). Although the anticancer effects of TBMS1 have been studied in various cancer cells, it remains unclear whether it sensitizes the CDDP-resistant ovarian cancer cells to CDDP-induced cytotoxicity and which molecular mechanisms are involved. Therefore, the aim of this study was to elucidate the effects of TBMS1 on CDDP-resistant cells and to identify its mechanism of action. To our knowledge, this is the first study to focus on the therapeutic efficacy of TBMS1 in combination with CDDP in A2780/DDP cells in platinum-resistant ovarian cancer.

In this study, to determine whether TBMS1 is capable of promoting CDDP-induced apoptosis in A2780/DDP cells, a low dose of CDDP $(6 \mu \mathrm{mol} / \mathrm{l})$ and TBMS1 $(8 \mu \mathrm{mol} / \mathrm{l})$ was used in a series of experimental studies. Cellular proliferation was found to be suppressed (Figs. 1 and 2). A previous study has indicated that the increased $\mathrm{Ca}^{2+}$ influx might regulate the apoptotic process by modulating the activities of the MAPK cascades, which are vital to cell survival or death (32). However, in the present study, it was observed that TBMS1 significantly increased the CDDP-induced $\mathrm{Ca}^{2+}$ influx in A2780/DDP cells (Fig. 3). The results suggest that TBMS1 has the capacity to sensitize CDDP in A2780/DDP cells.

The members of the Bcl-2 family act as anti- or proapoptotic regulators that are involved in a wide variety of cellular activities. Bcl-2 is the first gene proven to be a negative regulator of cell death and to protect cells from undergoing apoptosis induced by exogenous stimuli, whereas Bax is a proapoptotic regulator that promotes or accelerates cell death (33). Our results provide evidence that the activation of the intrinsic apoptotic pathway via a Bcl-2 and Bax-dependent mechanism could be a possible mechanism by which TBMS1 enhances CDDP-induced apoptosis (Fig. 4). Notably, the overall apoptotic response was significantly higher in the cells dually exposed to TBMS1 and $6 \mu \mathrm{mol} / 1 \mathrm{CDDP}$ than in the cells treated with $6 \mu \mathrm{mol} / 1 \mathrm{CDDP}$ alone. This further explains how TBMS1 promotes CDDP-induced apoptosis in A2780/DDP cells.

To further elucidate the mechanism by which TBMS1 sensitizes CDDP-resistant human ovarian cancer cells, we determined how the MAPKs regulate TBMS1 in CDDPinduced apoptosis. MAPKs are a family of serine/threonine kinases that play a critical role in cellular responses to various extracellular stimuli, including cell survival and apoptosis (34). The activation of ERK is generally associated with the inhibition of apoptosis, while the phosphorylation of p38 promotes apoptosis (35). TBMS1 has been shown to reduce the resistance of CDDP-resistant human ovarian cancer cells to low-dose CDDP-induced cell death through the downregulation of the ERK1/2 and the up-regulation of the p38 signaling pathways via Bcl-2 and Bax (Fig. 5).

To confirm the role of p38 and ERK1/2, cells were preincubated with the specific p38 inhibitor (SB203580) and ERK1/2 inhibitor (PD98059) for $1 \mathrm{~h}$ followed by treatment with TBMS1-CDDP for $24 \mathrm{~h}$. In this study, we show that pretreatment of the cells with p38 and ERK1/2 inhibitors significantly blocks these effects in TBMS1-CDDP-treated A2780/DDP cells (Fig. 6). The results show that p38 and ERK1/2 signaling pathways mechanistically regulate TBMS1-CDDP-induced apoptosis. It is well known that there are three main members of the MAPK family: The c-Jun N-terminal 39 kinase (JNK), p38 and the extracellular signal-regulated kinase (ERK1/2). However, no change was noted for JNK following drug treatment in this study, thus it is not discussed any further.

The GST family of phase II metabolizing enzymes catalyzes detoxifying endogenous reactions and protects cellular macromolecules from damage from cytotoxic, mutagenic, 
carcinogenic and chemotherapeutic agents (36). Among the GST family, GST- $\pi$ is widely expressed in various human epithelial tissues (37), and is common in ovarian tumors (38). GST- $\pi$ interacts with platinum-based compounds $(39,40)$, and high levels of this enzyme have been shown to be associated with drug resistance (41). In this study, we show that a combination of TBMS1 and CDDP results in a greater decrease not only in the mRNA expression but also in the protein expression of A2780/DDP cells, compared to the control cells (Fig. 7). The results further confirm that TBMS1 is capable of reducing the resistance of A2780/DDP cells to CDDP-induced cytotoxicity.

In conclusion, these results indicate that TBMS1 has significant anti-proliferative effects on CDDP-resistant human ovarian cancer A2780/DDP cells by inducing apoptosis and down-regulating CDDP-resistant genes. The effect is mediated through the regulation of the $\mathrm{p} 38$ and ERK1/2 pathways. Based on these observations, it is concluded that the TBMS1 combination serves as a potential therapeutic agent in the treatment of resistant human ovarian cancers. In vivo experiments will be carried out in a future study.

\section{Acknowledgements}

This study was supported by the National Natural Science Foundation of China (Project no. 30973169) and the Natural Science Foundation of Chongqing (Project no. CSTC2009BA5083). The authors are grateful to Chuang Yang for his critical reading and kind help in editing the manuscript, and would like to thank Yan Wang for the linguistic editing.

\section{References}

1. Reed E: Platinum-DNA adduct, nucleotide excision repair and platinum based anticancer chemotherapy. Cancer Treat Rev 24 331-344, 1998.

2. Stewart JJ, White JT, Yan X, Collins S, Drescher CW, Urban ND, Hood L and Lin B: Proteins associated with Cisplatin resistance in ovarian cancer cells identified by quantitative proteomic technology and integrated with mRNA expression levels. Mol Cell Proteomics 5: 433-443, 2006.

3. Vasey PA: Resistance to chemotherapy in advanced ovarian cancer: mechanisms and current strategies. Br J Cancer 89: S23-S28, 2003.

4. Arafa el-SA, Zhu Q, Barakat BM, Wani G, Zhao Q, El-Mahdy MA and Wani AA: Tangeretin sensitizes cisplatin-resistant human ovarian cancer cells through downregulation of phosphoinositide 3-kinase/Akt signaling pathway. Cancer Res 69: 8910-8917, 2009.

5. Wang F, Ma R and Yu L: Role of mitochondria and mitochondrial cytochrome $\mathrm{c}$ in tubeimoside I-mediated apoptosis of human cervical carcinoma HeLa cell line. Cancer Chemother Pharmacol 57: 389-399, 2006.

6. Cory S and Adams JM: The Bcl2 family: regulators of the cellular life-or-death switch. Nat Rev Cancer 2: 647-656, 2002.

7. Chipuk JE, Fisher JC, Dillon CP, Kriwacki RW, Kuwana T and Green DR: Mechanism of apoptosis induction by inhibition of the anti-apoptotic BCL-2 proteins. Proc Natl Acad Sci USA 105: 20327-20332, 2008.

8. Tsujimoto Y and Shimizu S: VDAC regulation by the Bcl-2 family of proteins. Cell Death Differ 7: 1174-1181, 2000.

9. Bishopric NH, Andreka P, Slepak T and Webster KA: Molecular mechanisms of apoptosis in the cardiac myocyte. Curr Opin Pharmacol 1: 141-150, 2001.

10. Maxwell SA, Acosta SA and Davis GE: Induction and alternative splicing of the Bax gene mediated by p53 in a transformed endothelial cell line. Apoptosis 4: 109-114, 1999.

11. Martinez-Caballero S, Dejean LM, Jonas EA and Kinnally KW: The role of the mitochondrial apoptosis induced channel MAC in cytochrome c release. J Bioenerg Biomembr 37: 155-164, 2005 .
12. Galan-Moya EM, Hernandez-Losa J, Aceves Luquero CI, De la Cruz-Morcillo MA, Ramírez-Castillejo C, Callejas-Valera JL, Arriaga A, Aranburo AF, Ramón y Cajal S, Silvio Gutkind J, et al: c-Abl activates p38 MAPK independently of its tyrosine kinase activity: Implications in cisplatin-based therapy. Int J Cancer 122: 289-297, 2008.

13. Hanahan D and Weinberg RA: The hallmarks of cancer. Cell 100: 57-70, 2000.

14. Wada T and Penninger JM: Mitogen-activated protein kinases in apoptosis regulation. Oncogene 23, 2838-2849, 2004.

15. Bulavin DV and Fornace AJ Jr: p38 MAP kinase's emerging role as a tumor suppressor. Adv Cancer Res 92: 95-118, 2004.

16. Mo Z, Gao Y, Cao Y, Gao F and Jian L: An updating meta-analysis of the GSTM1, GSTT1, and GSTP1 polymorphisms and prostate cancer: a HuGE review. Prostate 69: 662-688, 2009.

17. Hayes JD and Strange RC: Glutathione S-transferase polymorphisms and their biological consequence. Pharmacology 61: 154-166, 2000.

18. Souiden Y, Mahdouani M, Chaieb K, Elkamel R and Mahdouani K: Polymorphisms of glutathione-S-transferase M1 and $\mathrm{T} 1$ and prostate cancer risk in a Tunisian population. Cancer Epidemiol 34: 598-603, 2010

19. Rebbeck TR: Molecular epidemiology of the human glutathione S-transferase genotypes GSTM1 and GSTT1 in cancer susceptibility. Cancer Epidemiol Biomarkers Prev 6: 733-743, 1997.

20. Beeghly A, Katsaros D, Chen H, Fracchioli S, Zhang Y, Massobrio M, Risch H, Jones B and Yu H: Glutathione S-transferase polymorphisms and ovarian cancer treatment and survival. Gynecol Oncol 100: 330-337, 2006.

21. Prislei S, Mariani M, Raspaglio G, Mozzetti S, Filippetti F, Ferrandina G, Scambia G and Ferlini C: RON and cisplatin resistance in ovarian cancer cell lines. Oncol Res 19: 13-22, 2010.

22. Wang Y, Niu XL, Qu Y, Wu J, Zhu YQ, Sun WJ and Li LZ: Autocrine production of interleukin-6 confers cisplatin and paclitaxel resistance in ovarian cancer cells. Cancer Lett 295: 110-123, 2010.

23. Ohmichi M, Hayakawa J, Tasaka K, Kurachi H and Murata Y: Mechanisms of platinum drug resistance. Trends Pharmacol Sci 26: 113-116, 2005.

24. Sarkar FH and Li Y: Using chemopreventive agents to enhance the efficacy of cancer therapy. Cancer Res 66: 3347-3350, 2006.

25. Bava SV, Puliappadamba VT, Deepti A, Nair A, Karunagaran D and Anto RJ: Sensitization of taxol-induced apoptosis by curcumin involves down-regulation of nuclear factor-kappaB and the serine/threonine kinase Akt and is independent of tubulin polymerization. J Biol Chem 280: 6301-6308, 2005.

26. Yu TX, Ma RD and Yu LJ: Structure-activity relationship of tubeimosides in anti-inflammatory, antitumor, and antitumorpromoting effects. Acta Pharmacol Sin 22: 463-468, 2001.

27. Cheng G, Zhang Y, Zhang X, Tang HF, Cao WD, Gao DK and Wang XL: Tubeimoside V (1), a new cyclic bisdesmoside from tubers of Bolbostemma paniculatum, functions by inducing apoptosis in human glioblastoma U87MG cells. Bioorg Med Chem Lett 16: 4575-4580, 2006.

28. Yu L, Ma R and Yu T: Induction of morphological and functional differentiation of human promyelocytic leukemia cells (HL-60) by Tubeimoside 1. Planta Med 62: 119-121, 1996.

29. Xu Y,Chiu JF,He QY and Chen F: Tubeimoside-1 exerts cytotoxicity in HeLa cells through mitochondrial dysfunction and endoplasmic reticulum stress pathways. J Proteome Res 8: 1585-1593, 2009.

30. Weng XY, Ma RD and Yu LJ: Apoptosis of human nasopharyngeal carcinoma CNE-2Z cells induced by tubeimoside I. Ai Zheng (in Chinese) 22: 806-811, 2003.

31. Ma R, Song G, You W, Yu L, Su W, Liao M, Zhang Y, Huang L, Zhang $\mathrm{X}$ and $\mathrm{Yu} \mathrm{T}$ : Anti-microtubule activity of tubeimoside I and its colchicine binding site of tubulin. Cancer Chemother Pharmacol 62: 559-568, 2008.

32. Chen MJ, Nguyen TV, Pike CJ and Russo-Neustadt AA: Norepinephrine induces BDNF and activates the PI-3K and MAPK cascades in embryonic hippocampal neurons. Cell Signal 19: 114-128, 2007.

33. Chang CW, Tsai WH, Chuang WJ, Lin YS, Wu JJ, Liu CC, Tsai PJ and Lin MT: Procaspase 8 and Bax are up-regulated by distinct pathways in Streptococcal pyrogenic exotoxin B-induced apoptosis. J Biol Chem 284: 33195-33205, 2009.

34. Singhal PC, Bhaskaran M, Patel J, Patel K, Kasinath BS, Duraisamy S, Franki N, Reddy K and Kapasi AA: Role of p38 mitogen-activated protein kinase phosphorylation and Fas-Fas ligand interaction in morphine-induced macrophage apoptosis. J Immunol 168: 4025-4033, 2002. 
35. Porras A, Zuluaga S, Black E, Valladares A, Alvarez AM, Ambrosino C, Benito $M$ and Nebreda AR: P38 alpha mitogenactivated protein kinase sensitizes cells to apoptosis induced by different stimuli. Mol Biol Cell, 15: 922-933, 2004.

36. Strange RC, Spiteri MA, Ramachandran S and Fryer AA: Glutathione-S-transferase family of enzymes. Mutat Res 482: 21-26, 2001.

37. Terrier P, Townsend AJ, Coindre JM, Triche TJ and Cowan KH: An immunohistochemical study of pi class glutathione S-transferase expression in normal human tissue. Am J Pathol 137: $845-853,1990$

38. Orlandi A, Costantini S, Campione E, Ferlosio A, Amantea A, Bianchi L, Chimenti S and Spagnoli LG: Relation between animal-type melanoma and reduced nuclear expression of glutathione S-transferase pi. Arch Dermatol 145: 55-62, 2009.
39. Tsuchida S and Sato K: Glutathione transferases and cancer. Crit Rev Biochem Mol Biol 27: 337-384, 1992.

40. Goto S, Kamada K, Soh Y, Ihara Y and Kondo T: Significance of nuclear glutathione S-transferase pi in resistance to anticancer drugs. Jpn J Cancer Res 93: 1047-1056, 2002.

41. Cheng X, Kigawa J, Minagawa Y, Kanamori Y, Itamochi H, Okada $\mathrm{M}$ and Terakawa N: Glutathione S-transferase-pi expression and glutathione concentration in ovarian carcinoma before and after chemotherapy. Cancer 179: 521-527, 1997. 